\title{
Influence of native vegetation on pequiá fruit (Caryocar villosum [Aubl.] Pers) production and traits
}

\author{
Bruna Maria Roldão LOPES ${ }^{1}$, Oriales Rocha PEREIRA ${ }^{1}$, Clarissa Fernandes ${ }^{1}$, \\ Joaquim Manoel da SILVA ${ }^{1,2^{*}}$
}

\begin{abstract}
${ }^{1}$ Faculdade de Ciências Agrárias, Biológicas e Sociais, Universidade Estadual de Mato Grosso, Nova Xavantina, MT, Brasil. (Orcid: 0000-0003-2767-5609; 0000-0003-0921-5449; 0000-0002-1886-4005; *)

${ }^{1}$ Programa de Pós-Graduação em Ecologia e Conservação, Universidade Estadual de Mato Grosso, Nova Xavantina, MT, Brasil. *E-mail: joaquimmanoel@unemat.br (Orcid: 0000-0002-4046-1405)
\end{abstract}

Recebido em 15/04/2020; Aceito em 14/09/2020; Publicado em 28/09/2020.

\begin{abstract}
This study aims to determine the influence of native vegetation on production and traits of fruit from pequiá (Caryocar villosum [Aubl.] Pers), in the city of Nova Xavantina, Mato Grosso, Brazil. Fruits were collected from pequiá trees from two sites over a three-year period (2016, 2017, and 2018). The first site (Property A) was located near a fragment of natural vegetation, and the second site (Property B) was located in an anthropized area, far from any fragments of vegetation. The fruit samples $(N=40)$ were taken to the laboratory and, using a digital scale and calipers, each fruit's weight, the weight of the outer shell, the equatorial diameter of the fruit, the longitudinal diameter of the fruit, the equatorial diameter of the seed, the longitudinal diameter of the seed, the thickness of the outer shell, and the number of seeds per fruit were measured or counted. The pequia seeds were separated into batches of ten to evaluate the weight with pulp, their weight without pulp, the weight of the pulp, and the pulp yield as variables. Student's t-test was used to compare the fruit traits between the two sites. Analysis of variance was also applied to the data. Property A was found to have larger and heavier fruits and a higher pulp weight in each batch. The climate may have been the main factor that influenced pequiá production from one year to the next during the study period. A lack of vegetation is one of the causes of distancing and reductions in pollinators, which, in turn, directly influence production and traits of pequiá fruits.
\end{abstract}

Keywords: ecosystem services; pollination; climate.

\section{Influência da vegetação nativa na produção e biometria de frutos de pequiá (Caryocar villosum [Aubl.] Pers)}

\begin{abstract}
RESUMO: O objetivo deste trabalho foi verificar a influência da vegetação nativa na produção e biometria de frutos de pequiás (Caryocar villosum [Aubl.] Pers) em Nova Xavantina, Mato Grosso, Brasil. Para a realização deste estudo foram feitas coletas de frutos de pequiá em duas áreas durante três anos (2016, 2017 e 2018). Sendo a primeira área localizada próximo de um fragmento de vegetação natural (Propriedade A) e a segunda área está situada em área antropizada e distante de qualquer fragmento de vegetação (Propriedade B). Em cada propriedade foram coletados 40 frutos maduros de pequiá. Os frutos foram levados para laboratório e com o auxílio de uma balança digital e paquímetro avaliaram-se os seguintes parâmetros: peso do fruto, peso da casca, diâmetro equatorial do fruto, diâmetro longitudinal do fruto, diâmetro equatorial do caroço, diâmetro longitudinal do caroço, espessura da casca e número de caroços por fruto. Os caroços de pequiá foram separados em lotes de dez unidades para avaliar as variáveis de peso com polpa, peso sem polpa, peso da polpa e rendimento da polpa. Para a comparação das variáveis biométricas entre as propriedades foi utilizado o teste t de Student, já para o fator ano os dados foram submetidos à análise de variância. A propriedade A apresentou frutos maiores, mais pesados e com maior peso de polpa por lotes. O clima foi possivelmente o principal fator que influenciou na produção dos pequiás entre os anos analisados. A ausência de vegetação é um dos motivos que causa distanciamento e redução dos polinizadores, influenciando diretamente na produção e biometria dos frutos de pequiás.

Palavras-chave: serviço ecossistêmico; polinização; clima.
\end{abstract}

\section{INTRODUCTION}

Caryocar villosum (Aubl.) Pers is a fruit-bearing tree in the family Caryocaraceae (MEDEIROS; AMORIM, 2020). This species is commonly and locally known as the pequiá. It is found in forests and in cerrado stricto sensu ecosystems within the Cerrado biome (MEDEIROS; AMORIM, 2020) and in the central Amazon rainforest (MARTINS; GRIBEL, 2007) in Brazil. As a result of its planting on small orchards, this species is commonly found in many cities within the Araguaia Valley, located in the eastern region of Mato Grosso State.

Pequiá fruit is used in a variety of ways. Most frequently, the pulp is eaten raw. It is rich in $\beta$-carotene and can also be used to produce sweets, jams, liqueurs, and oils (KINUPP; LORENZI, 2014). According to Nascimento-Silva; Naves, 
(2019), Caryocar spp. pulp is an important source of carotenoids, but the amounts and types of carotenoids may vary among them. The same study suggests that the supplementation of pequi oil in animal models has demonstrated antioxidant, anti-inflammatory, cardioprotective, hepatoprotective, antigenotoxic, and anticarcinogenic effects.

C. villosum is pollinated by bats, a fact which reflects the value of these two species for their role in maintaining the forest's ecosystem (UIEDA; BRED, 2016). Thus, conserving nectarivorous bats and their natural habitats helps to ensure the production of pequiá trees for both animals and humans (BPBES, 2019).

According to Gribel (1986), bats with this eating habit, such as Glossophaga soricina (PALLAS, 1766), have a greater potential for pollinating pequi fruit (Caryocar brasiliense Cambess.), while moths, bees, and birds are cited as secondary pollinators because they are less efficient and effective at pollination than bats are. Pollination is considered an essential regulatory ecosystem service that provides many benefits to human beings; it is important for the production of fruits of a better quality, at a higher weight, and with a greater number of seeds (BPBES, 2019).

The term "ecosystem services" arose from the concepts of environmental services and human quality of life, which is maintained when these services aid in the regulation of the climate, in protection against natural disasters and soil erosion, and in the production of a variety of cultivars through pollination (ENCINA et al., 2018). Studies on ecosystem services have increased in Brazil in recent years and have contributed to our understanding of the importance of these services to maintaining pollinating animals involved in human food production (BPBES, 2019).

Many authors studying different fruit-bearing tree species have reported that the presence of pollinators is important for these trees to bear fruit. These same authors have found that the causes for decreased fruit production and quality are intense urbanization, substantial agricultural expansion, and habitat fragmentation, all of which have created gaps between sites with the native vegetation that provides food and shelter for pollinators (KRAUSE et al., 2012; YAMAMOTO et al., 2014).

Natural habitats and ecosystems in the Cerrado biome are being modified by crops and agroforestry. Fagundes et al. (2007) found that pollinating bats play an important role in the reproduction of species of the family Caryocaraceae, but that the bats activity is limited by habitat fragmentation.

For this reason, this study sought to determine the influence of native vegetation on the production and traits of C. villosum fruit in Nova Xavantina, Mato Grosso, Brazil.

\section{MATERIALS AND METHODS}

This study involved two sites in the city of Nova Xavantina, Mato Grosso State. Property A (Figure 1.A; $\left.14^{\circ} 42^{\prime} 03.6^{\prime \prime} \mathrm{S}, 52^{\circ} 21^{\prime} 27.1^{\prime \prime} \mathrm{W}\right)$ is located approximately $50 \mathrm{~m}$ from Bacaba Municipal Park, while Property B (Figure 1.B; $\left.14^{\circ} 38^{\prime} 31.15^{\prime \prime} \mathrm{S}, 52^{\circ} 21^{\prime} 44.23^{\prime \prime} \mathrm{W}\right)$ is located approximately 4 $\mathrm{km}$ from the city center, is isolated within an anthropized area, and is approximately $450 \mathrm{~m}$ from the nearest fragment of native vegetation.

Bacaba Municipal Park (14\%41'09" S and 52\%20'09” W) is a conservation area 492 hectares in size located in Nova Xavantina. Its prevalent vegetation is cerrado stricto sensu, though it also includes gallery forest, patches of cerradão forest (defined by its xerophytic vegetation and relatively tall trees), and savanna on rocky soil, known locally as cerrado rupestre (SILVÉRIO; LENZA, 2010).

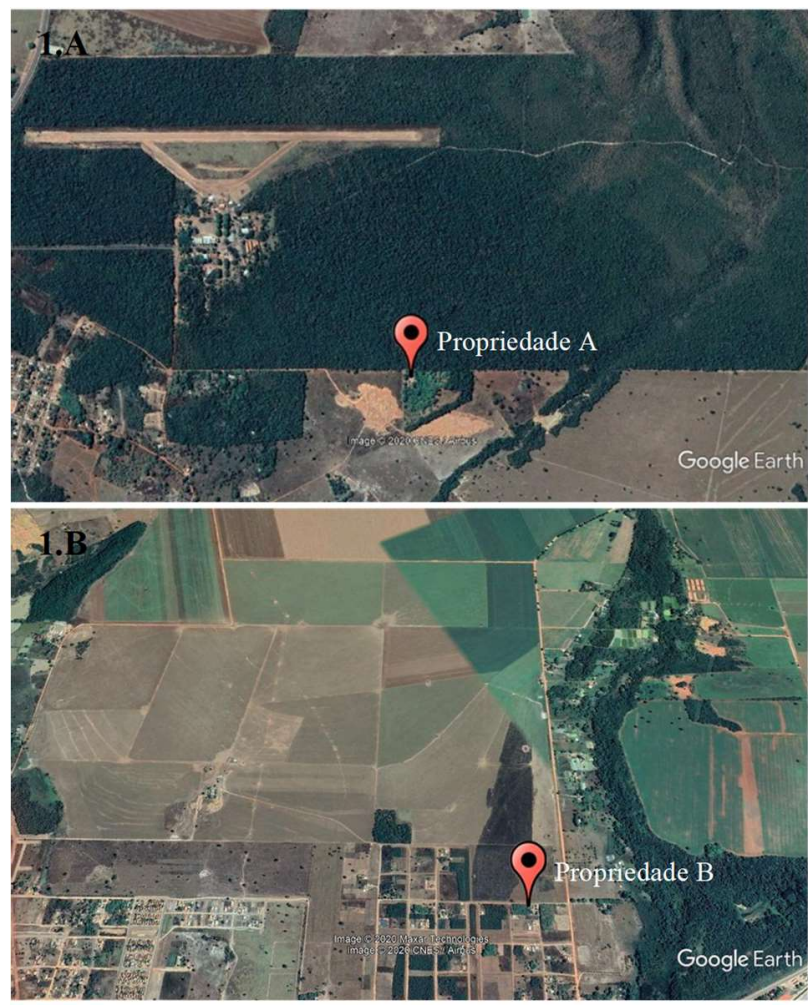

Figure 1. Study sites in Nova Xavantina, Mato Grosso, Brazil. 1.A: Property A located near a fragment of native vegetation (Bacaba Municipal Park); 1.B: Property B located far from any fragments of native vegetation. Source: Google Earth.

Figura 1. Sítios de estudo em Nova Xavantina, Mato Grosso, Brasil. Em 1.A: propriedade A situada próxima a fragmento de vegetação (Parque Municipal do Bacaba); 1.B: propriedade B distante de fragmento de vegetação nativa. Fonte: Google Earth.

The sites selected for study have commercial pequiá orchards and were chosen because of their locations relative to native vegetation. The amount of vegetation in the study areas shown in Figure 1 was quantified using Google Earth: Property A consisted of approximately $75.3 \%$ vegetation, while Property B consisted of approximately 15.5\% vegetation. Property A was established as the site close to a fragment of native vegetation because it is close to a conservation area, while Property B is located within the city limits and far from any vegetation fragments.

Data on water sources and temperature in the city of Nova Xavantina in 2016, 2017, and 2018 were obtained from the Brazilian National Meteorology Institute (INMET).

The fruit samples were collected at the end of the species' reproductive season in the region (during November and December) for three consecutive years (2016 to 2018). Forty C. villosum fruit samples were collected randomly from under the trees within the orchards on each property. They were collected when the fruit was ripe and abscission had already occurred. Only healthy and uninjured fruits were selected for the purposes of this study.

The fruits were taken to the chemistry laboratory of the Nova Xavantina campus of Mato Grosso State University (UNEMAT) to evaluate the fruit traits. The parameters evaluated were fruit weight, outer shell weight, and seed 
weight per fruit, which were measured in grams using a digital scale, as well as the equatorial diameter of the fruit, the longitudinal diameter of the fruit, the equatorial diameter of the seed, the longitudinal diameter of the seed, and the thickness of the outer shell, all of which were measured in millimeters using digital calipers. When the fruits had more than one seed, the mean equatorial and longitudinal diameters of the seeds were calculated. The number of seeds per fruit were also counted during the analysis. Small (undeveloped) seeds were not included in the fruit trait analyses.

Next, the seeds were separated into batches of ten. Each batch was boiled for approximately 40 minutes to make pulp removal easier. The pulp parameters evaluated were fruit weight with pulp, fruit weight without pulp, pulp weight, and pulp yield. To calculate pulp yield, the weight without pulp was subtracted from the weight with pulp. Pulp weight was measured in grams using a digital scale.

The data of each parameter in each year of the study were charted and the distributions were found to be normal or approximately normal according to a graph-based analysis. The variability of the data was homogenous. Next, an analysis of variance was applied to the fruit trait variables (with the year as the factor), and the means of the significant variables were compared using Tukey's test at a significance level of $1 \%$. To compare the fruit traits between the two study sites, Student's t-test was used at a significance level of $1 \%$. The Pearson correlation coefficient ( $r$ ) was applied, and the significance level ( $\mathrm{p}$ ) was determined between the variables using the t-test. An analysis of variance was performed for the multiple linear regression in order to determine which variables could be influencing fruit weight. SigmaPlot, version 10 was used to build the climograph. The descriptive statistical analysis, the Pearson correlation test, and the multiple linear regression test were performed in PAST, version 2.17 .

\section{RESULTS}

The data on climactic variables (temperature and rainfall) exhibited seasonal patterns with two well-defined periods: the rainy season and the dry season. Rainfall was lowest in June and July in 2016 and in 2018; in 2017, it was lowest in July and August, during which time no rainfall was recorded. The highest rainfall occurred in December in 2016 (367.3 $\mathrm{mm}$ ), in January in 2017 (395.5 mm), and in November in 2018 (328.5 mm). Temperature values also varied slightly. The highest temperature recorded in 2016 was $38^{\circ} \mathrm{C}$ in September; the highest temperature in 2017 was $38^{\circ} \mathrm{C}$, which was recorded every month between September and December, and the highest temperature in 2018 was $37^{\circ} \mathrm{C}$ in September. In all three years of the study, the lowest temperature recorded was $13^{\circ} \mathrm{C}$ in July (Figure 2).

When interpreting the correlations, results with $1 \%$ probability according to the t-test were considered significant. The correlations for Property A for the year 2016 demonstrated that fruit weight was positively correlated with the equatorial diameter of the fruit, the longitudinal diameter of the fruit, outer shell weight, and seed weight per fruit. The equatorial diameter of the fruit was significantly correlated with outer shell weight and seed weight per fruit. The longitudinal diameter of the fruit was correlated only with outer shell weight. Outer shell thickness was positively correlated with outer shell weight and the equatorial diameter of the seed. Outer shell weight was significantly correlated only with seed weight per fruit. The Property B fruit correlation patterns observed in 2016 repeated in 2017 and 2018.
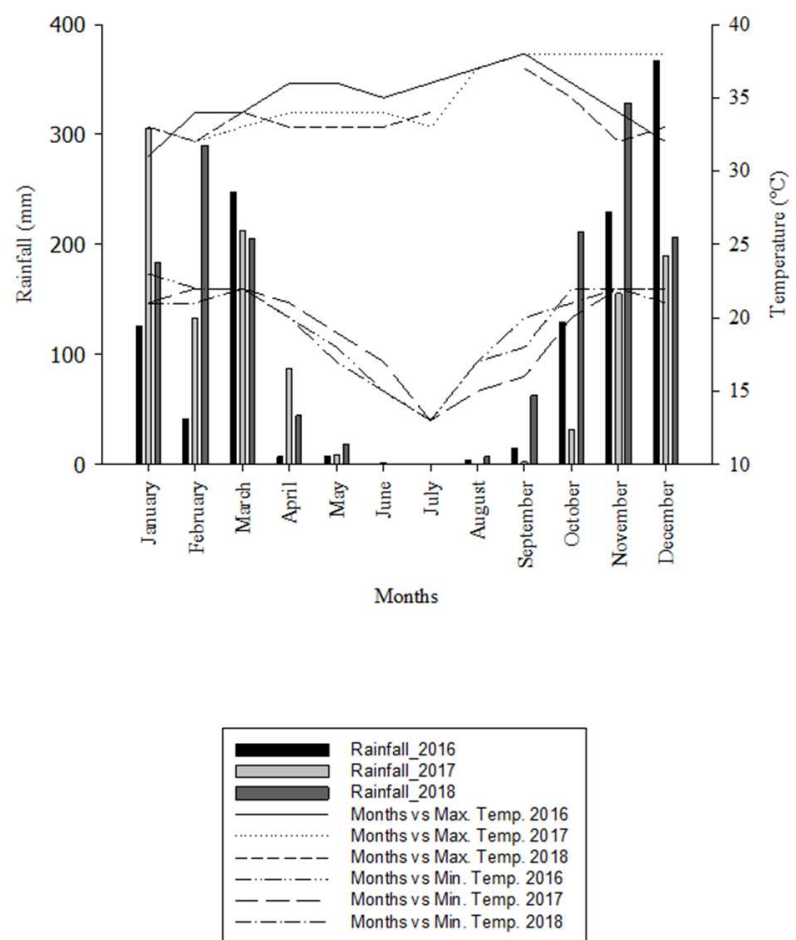

Figure 2. Climograph for the city of Nova Xavantina, Mato Grosso, Brazil for 2016, 2017, and 2018. Where: Annual rainfall in millimeters $(\mathrm{mm})$ represented by bars; lowest and highest temperature in Celsius $\left({ }^{\circ} \mathrm{C}\right)$ represented by lines. Source: Brazilian National Meteorology Institute (INMET).

Figura 2. Climatograma para o município de Nova Xavantina - Mato Grosso, dos anos de 2016, 2017 e 2018. Sendo: Precipitação anual em milímetros $(\mathrm{mm})$ representada por barras; temperatura máxima e mínima em graus Celsius $\left({ }^{\circ} \mathrm{C}\right)$ representada por linhas. Fonte: Instituto Nacional de Meteorologia (INMET).

The correlations for Property B for the year 2016 demonstrated that fruit weight was positively correlated with the equatorial diameter of the fruit, the longitudinal diameter of the fruit, outer shell thickness outer shell weight, seed weight per fruit, and the longitudinal diameter of the seed. The equatorial diameter of the fruit was significantly correlated with outer shell weight and seed weight per fruit. The results were consistent in 2018. The longitudinal diameter of the fruit was correlated with outer shell thickness, outer shell weight, seed weight per fruit, equatorial diameter of the seed, and longitudinal diameter of the seed. Outer shell thickness was positively correlated with outer shell weight and the longitudinal diameter of the seed. Outer shell weight was significantly correlated with seed weight per fruit and the longitudinal diameter of the seed. The equatorial diameter of the seed was significantly correlated with the longitudinal diameter of the seed. The Property B fruit correlation patterns observed in 2016 repeated in 2017 and 2018.

Many variables were analyzed, but not all of them were found to be important for explaining fruit weight. The analysis showed that outer shell weight and seed weight per fruit, with respective coefficients of determination of 0.905 
and 0.587 , had a significant effect on fruit weight; in other words, these variables influenced pequiá fruit weight (Table 1). This result is consistent with those observed in the correlation analyses, in which multicollinearity was observed between the fruit traits studied herein.

Table 1. Multiple linear regression analysis for the variable fruit weight of the pequia fruit (Caryocar villosum [Aubl.] Pers) from two sites in Nova Xavantina, Mato Grosso, Brazil in 2016, 2017 and 2018.

Tabela 1. Análise de regressão linear múltipla para a variável peso do fruto de pequiá (Caryocar villosum [Aubl.] Pers) de dois sítios em Nova Xavantina, Mato Grosso, Brasil em 2016, 2017 e 2018.

\begin{tabular}{llllll}
\hline & $\mathrm{C}$ & $\mathrm{SE}$ & $\mathrm{T}$ & $\mathrm{P}$ & $\mathrm{R}^{2}$ \\
\hline Const. & 2362.300 & 3364.500 & 0.702 & 0.483 & \\
YEAR & -1.178 & 1.667 & -0.707 & 0.480 & 0.076 \\
PROP. & 2.123 & 2.905 & 0.731 & 0.466 & 0.097 \\
EDF & 0.231 & 0.165 & 1.404 & 0.162 & 0.675 \\
LDF & 0.282 & 0.139 & 2.019 & 0.045 & 0.323 \\
ST & 0.786 & 0.425 & 1.848 & 0.066 & 0.072 \\
OSW & 0.921 & 0.028 & 33.112 & $0.000 *$ & 0.905 \\
SW & 1.067 & 0.061 & 17.386 & $0.000 *$ & 0.587 \\
EDS & -0.364 & 0.238 & -1.533 & 0.127 & 0.042 \\
LDS & -0.246 & 0.207 & -1.185 & 0.237 & 0.105 \\
\hline
\end{tabular}

Const.: constant; PROP.: property; EDF: equatorial diameter of the fruit; LDF: longitudinal diameter of the fruit; ST: thickness of the outer shell; OSW: outer shell weight; SW: seed weight per fruit; EDS: equatorial diameter of the seed; LDS: longitudinal diameter of the seed; C: coefficient of multiple linear regression; SE: standard error.

*Significant at $1 \%$ probability according to the t-test.

A general descriptive analysis of the pequia fruit variables is presented in Table 2. The coefficient of variation of all of the parameters ranged from $8.56 \%$ to $43.67 \%$. Because this was an uncontrolled field experiment, this variation was expected (PIMENTEL-GOMES; GARCIA, 2002). All mean parameter values were higher among fruit from Property A than among those from Property B. The analysis revealed a significant difference between the two properties in terms of fruit weight, equatorial diameter of the fruit, longitudinal diameter of the fruit, outer shell weight, seed weight per fruit, equatorial diameter of the seed, longitudinal diameter of the seed, fruit weight with pulp, fruit weight without pulp, pulp weight, and pulp yield. Only outer shell thickness did not differ significantly between the two properties.

When fruit weight and equatorial diameter of the fruit were considered, fruits from 2016 and 2017 differed significantly from 2018, but fruits from 2016 and 2017 did not differ significantly from each other.

Longitudinal diameter of the fruit and pulp yield in 2016 did not differ significantly from these same parameters in 2017 or 2018, but these parameters in 2017 differed significantly from those in 2018. Outer shell thickness was the only 2016 parameter that differed significantly from its 2017 and 2018 values, though 2017 and 2018 did not differ significantly from each other. Seed weight per fruit differed significantly between 2017 and 2018, though this parameter in 2016 did not differ significantly from this same parameter in 2017 or 2018. Neither outer shell weight, equatorial diameter of the seed, longitudinal diameter of the seed, fruit weight with pulp, fruit weight without pulp, nor pulp weight differed significantly between 2016, 2017, or 2018.

\section{DISCUSSION}

Climactic seasonality in the study region has been reported by other authors (OLIVEIRA, 2008; REAIS et al.,
2016). This seasonal climate may influence the production of plant species from natural environments, as was determined by Zuffo et al. (2014) in a study on the fruit traits of baru (Dipteryx alata Vog.) fruits and seeds.

According to Oliveira (2008) and Faria et al. (2015), fruit from Cerrado plants typically matures heterogeneously across the biome, with a tendency for fleshy fruits to set and spread during the rainy season in such a way that they are synchronized with the increased activity of their seed dispersers during this period of the year. Similar to our findings, Freitas et al. (2016) performed a phenological characterization study of three forest species from 1997 to 1999 and found that C. villosum set from November to March, a period coinciding with the rainy season.

Though total rainfall levels were similar across the three years of our study, rain distribution differed from one month to the next and therefore may have influenced pequia fruit production during the sampling periods. The fruit samples collected in 2017 were smaller terms of fruit trait measurements, and this was also the year with the lowest rainfall during the rainy season (the period in which the tree also bore fruit). Alves et al. (2014) found a high variability in the physical characteristics of pequi fruit (C. brasiliense) and argued that soil and climate conditions, such as total rainfall and soil type, may play a role in the high coefficients of variation in their results. Water availability is the main limiting factor for plant species growth and reproduction, and it influences the traits of fruits and seeds (ZUFFO et al., 2014; FARIA et al., 2015).

The Pearson correlation test can be used when there is a feature of interest that is difficult to assess. If this feature is positively correlated with an easy-to-assess feature, it can be deduced that the increase in the feature is accompanied by the increase in the other, and vice versa (MOURA et al., 2004). According to Zuffo et al. (2016), the Spearman correlation values they acquired in their study of fruit from the Buchenavia tomentosa tree (a fruit known locally as tarumarana) reflected a significant correlation between fruit size, mass, and volume.

Moura et al. (2013) provided physical characterizations of pequi fruit (C. brasiliense) from the Cerrado and found a significant positive correlation between total fruit mass and total seed mass per fruit; total fruit mass was also found to be highly correlated with other dimensional parameters of the fruit. The correlation found between outer shell weight and seed weight per fruit, which influenced fruit weight, was also observed by Nascimento; Cocozza, (2015).

The pequiá fruit from the site near Bacaba Municipal Park (Property A) were larger and heavier and had a higher pulp weight per batch. The pequiá fruit samples from the site located far from any vegetation fragments (Property B) were smaller in terms of their traits and reflected inferior production than those collected from Property A. It is important for fruit-bearing trees to be located near fragments of native vegetation. These fragments provide shelter for pollinators that contribute to the reproductive success of these plant species (YAMAMOTO et al., 2014). When they are properly pollinated by insects or animals, these plants produce more and higher-quality fruits and seeds (BPBES, 2019).

Bats have also been determined to be the most important pollinators of $C$. villosum because of the frequency with which they visit the inflorescences and because of their ability to cross long distances before dispersing the seeds (MARTINS; 
GRIBEL, 2007). However, intense deforestation and habitat fragmentation have contributed to the distancing of or reduction in specific pollinators, which, in turn, negatively effects the efficacy of plant species reproduction. According to Krause et al. (2012), the bumblebee population in the city of Tangara da Serra, Mato Grosso, Brazil, was not sufficient to pollinate passion fruit orchards. This insufficient bumblebee population is likely caused by intense urbanization the and substantial expansion of agriculture in the region, which have reduced the amount of native vegetation available for these pollinators.

Table 2. Trait parameters of the pequiá fruit (Caryocar villosum [Aubl.] Pers) collected from two sites (Property A located near Bacaba Municipal Park; Property B located far from any fragments of native vegetation) in the city of Nova Xavantina, Mato Grosso, Brazil, in 2016, 2017 and 2018.

Tabela 2. Parâmetros biométricos de pequiá (Caryocar villosum [Aubl.] Pers) em dois sítios (Proriedade A localizada próxima ao Parque Municipal do Bacaba; Propriedade B localizada distante de fragmentos de vegetação nativa) na cidade de Nova Xavantina, Mato Grosso, Brazil, em 2016, 2017 e 2018.

\begin{tabular}{lllllllllll}
\hline & \multicolumn{3}{c}{ Fruit Weight } & \multicolumn{5}{c}{ Equatorial Diameter of the Fruit } \\
\hline & Property & \multicolumn{3}{c}{ Year } & & & Property & \multicolumn{3}{c}{ Year } \\
& A & $\mathrm{B}$ & 2016 & 2017 & 2018 & $\mathrm{~A}$ & $\mathrm{~B}$ & 2016 & 2017 & 2018 \\
\hline $\mathrm{N}$ & 120 & 120 & 80 & 80 & 80 & 120 & 120 & 80 & 80 & 80 \\
Mean & $387.13 \mathrm{a}$ & $307.68 \mathrm{~b}$ & $323,11 \mathrm{a}$ & $310,02 \mathrm{a}$ & $409,10 \mathrm{~b}$ & $96,61 \mathrm{a}$ & $91,08 \mathrm{~b}$ & $90,07 \mathrm{a}$ & $91,21 \mathrm{a}$ & $100,24 \mathrm{~b}$ \\
SD & 123.22 & 119.54 & 100,46 & 112,3 & 143,59 & 15,84 & 15,17 & 13,45 & 16,64 & 15,07 \\
CV (\%) & 31.83 & 38.85 & 31,09 & 36,23 & 35,1 & 16,39 & 16,66 & 14,93 & 18,24 & 15,04
\end{tabular}

\begin{tabular}{lllllllllll}
\hline & \multicolumn{4}{c}{ Longitudinal Diameter of the Fruit } & \multicolumn{5}{c}{ Outer Shell Thickness } \\
\hline & Property & \multicolumn{3}{c}{ Year } & Pear & Property & \multicolumn{3}{c}{ Year } \\
& A & B & 2016 & 2017 & 2018 & A & B & 2016 & 2017 & 2018 \\
\hline N & 120 & 120 & 80 & 80 & 80 & 120 & 120 & 80 & 80 & 80 \\
Mean & $82.95 \mathrm{a}$ & $74.92 \mathrm{~b}$ & $78,30 \mathrm{a}$ & $75,71 \mathrm{aa}$ & $82,80 \mathrm{ab}$ & $14,97 \mathrm{a}$ & $13,62 \mathrm{a}$ & $16,57 \mathrm{a}$ & $12,90 \mathrm{~b}$ & $13,41 \mathrm{~b}$ \\
$\mathrm{SD}$ & 13.97 & 9.11 & 9,19 & 7,34 & 17,43 & 3,83 & 5,03 & 4,49 & 3,7 & 4,42 \\
$\mathrm{CV}(\%)$ & 16.84 & 12.16 & 11,74 & 9,7 & 21,04 & 25,57 & 36,89 & 27,11 & 28,72 & 32,96
\end{tabular}

\begin{tabular}{lllllllllll}
\hline & \multicolumn{4}{c}{ Outer Shell Weight } & \multicolumn{5}{c}{ Seed Weight per Fruit } \\
\hline & Property & \multicolumn{3}{c}{ Year } & & & Property & Year & \\
& A & B & 2016 & 2017 & 2018 & A & B & 2016 & 2017 & 2018 \\
\hline N & 120 & 120 & 80 & 80 & 80 & 120 & 120 & 80 & 80 & 80 \\
Mean & $277.05 \mathrm{a}$ & $218.29 \mathrm{~b}$ & $244,36 \mathrm{a}$ & $209,64 \mathrm{a}$ & $289,01 \mathrm{a}$ & $112,92 \mathrm{a}$ & $87,38 \mathrm{~b}$ & $78,20 \mathrm{a}$ & $100,86 \mathrm{aa}$ & $121,40 \mathrm{ab}$ \\
$\mathrm{SD}$ & 92.34 & 95.47 & 76,47 & 82,72 & 115,32 & 43,48 & 38,15 & 33,68 & 38,96 & 44,03 \\
CV (\%) & 33.33 & 43.73 & 31,29 & 39,46 & 39,9 & 38,51 & 43,67 & 43,07 & 38,63 & 36,27
\end{tabular}

\begin{tabular}{|c|c|c|c|c|c|c|c|c|c|c|}
\hline & \multicolumn{5}{|c|}{ Equatorial Diameter of the Seed } & \multicolumn{5}{|c|}{ Longitudinal Diameter of the Seed } \\
\hline & Property & & Year & & & Property & & Year & & \\
\hline & A & $\mathrm{B}$ & 2016 & 2017 & 2018 & A & $\mathrm{B}$ & 2016 & 2017 & 2018 \\
\hline $\mathrm{N}$ & 120.00 & 120.00 & 80.00 & 80.00 & 80.00 & 120.00 & 120.00 & 80.00 & 80.00 & 80.00 \\
\hline Mean & $44.82 \mathrm{a}$ & $38.97 \mathrm{~b}$ & $42.75 \mathrm{a}$ & $41.80 \mathrm{a}$ & $41.15 \mathrm{a}$ & $61.57 \mathrm{a}$ & $52.38 \mathrm{~b}$ & $55.85 \mathrm{a}$ & $56.87 \mathrm{a}$ & $58.20 \mathrm{a}$ \\
\hline $\mathrm{SD}$ & 5.75 & 5.57 & 7.71 & 5.55 & 5.56 & 8.07 & 5.02 & 8.70 & 6.24 & 9.09 \\
\hline \multirow[t]{4}{*}{$\mathrm{CV}(\%)$} & 12.82 & 14.29 & 18.03 & 13.27 & 13.50 & 13.10 & 9.58 & 15.58 & 10.98 & 15.62 \\
\hline & \multicolumn{5}{|c|}{ Weight with Pulp } & \multicolumn{5}{|c|}{ Weight without Pulp } \\
\hline & Property & & Year & & & Property & & Year & & \\
\hline & A & B & 2016 & 2017 & 2018 & A & B & 2016 & 2017 & 2018 \\
\hline $\mathrm{N}$ & 15 & 15 & 10 & 10 & 10 & 15 & 15 & 10 & 10 & 10 \\
\hline Mean & $722.30 \mathrm{a}$ & $487.31 \mathrm{~b}$ & $556.68 \mathrm{a}$ & $580.92 \mathrm{a}$ & $676.82 \mathrm{a}$ & $307.23 \mathrm{a}$ & $221.60 \mathrm{~b}$ & $267.48 \mathrm{a}$ & $234.35 \mathrm{a}$ & $291.42 \mathrm{a}$ \\
\hline SD & 102.22 & 60.80 & 136.37 & 102.28 & 173.18 & 26.31 & 37.85 & 57.27 & 49.70 & 42.90 \\
\hline \multirow[t]{4}{*}{$\mathrm{CV}(\%)$} & 14.15 & 12.48 & 24.50 & 17.61 & 25.59 & 8.56 & 17.08 & 21.41 & 21.21 & 14.72 \\
\hline & \multicolumn{5}{|c|}{ Pulp Weight } & \multicolumn{5}{|c|}{ Pulp Yield } \\
\hline & Property & & Year & & & Property & & Year & & \\
\hline & A & $\mathrm{B}$ & 2016 & 2017 & 2018 & A & B & 2016 & 2017 & 2018 \\
\hline $\mathrm{N}$ & 15 & 15 & 10 & 10 & 10 & 15 & 15 & 10 & 10 & 10 \\
\hline Mean & $375.00 \mathrm{a}$ & $234.11 \mathrm{~b}$ & $271.56 \mathrm{a}$ & $316.85 \mathrm{a}$ & $325.26 \mathrm{a}$ & $347.30 \mathrm{a}$ & $253.20 \mathrm{~b}$ & $285.12 \mathrm{a}$ & 264.06 aa & $351.56 \mathrm{ab}$ \\
\hline $\mathrm{SD}$ & 62.82 & 40.14 & 82.75 & 50.23 & 118.17 & 44.53 & 48.76 & 55.40 & 53.04 & 60.37 \\
\hline CV $(\%)$ & 16.75 & 17.14 & 30.47 & 15.85 & 36.33 & 12.82 & 19.26 & 19.43 & 20.08 & 17.17 \\
\hline
\end{tabular}

Significant at $1 \%$ probability according to the t-test and ANOVA.

$\mathrm{N}$ : number of fruit samples. SD: standard deviation; and CV: coefficient of variation.

A lack of pollinating insects has been reported in countless tree crops, including apple orchards (Malus domestica Borkh) and has resulted in a drop in production and lower fruit yields (HOLZSCHU et al., 2012). Garrat et al. (2014) studied apple tree pollination and found that pollinators influence not only fruit production quantity, but also quality, 
size, and weight, all of which affect the economic value of the fruit.

According to Nunes et al. (2016), pequi fruit (C. brasiliense and Caryocar coriaceum Wittm) are socioeconomically important in that they generate revenue for households during the harvest. They also provide rural communities with complementary income (AFONSO et al., 2015).

Natural environments play an important role in complex systems, providing ecosystem services such as climate control, rainfall system control through the release of humidity into the atmosphere through plants, and protection for soil through plant cover, which, in turn, guarantees a reserve of water resources (PANASOLO et al., 2019). The importance of barriers and/or windbreaks around crops has been reported by several authors (PROENÇA et al., 2016; PERUCH et al., 2018), who have provided evidence that barriers made of vegetation reduce wind speed within orchards and protect plants from pathogens.

The data obtained in the current study reflect the noteworthy importance of this research for understanding the processes and influential factors involved in pequiá orchard quality and production. Vegetation fragments near pequiá orchards are important because they provide ecosystem services such as maintaining pollinators and regulating weather/climate, both of which may have contributed to the production of larger fruit with larger pulp yields on Property A.

\section{CONCLUSION}

These approaches to C. villosum, ecosystem services, pollination, rainfall, and the Cerrado are important for understanding the factors that influence pequia quality and production. Variation in rainfall levels may have influenced fruit production in the years analyzed. This variation may explain the significant differences between the years and the tendency toward larger fruits and seeds in 2018, when there was more rainfall.

When the site near native vegetation was compared to the site near an urban area, the property near native vegetation was found to have larger and heavier fruits with higher pulp weight per batch, all of which increase the economic value of this fruit. The property located far from any native vegetation produced fruit with worse traits, which were likely caused by reduced pollination. A lack of vegetation is the main cause of the distancing of and reduction in pollinators, since there are no longer sufficient habitats located close enough to the crop to maintain the bat populations essential for pequiá pollination.

C. villosum still requires more analyses regarding the influence of the environment on its production and quality; therefore, more research is suggested to provide more knowledge on this topic.

\section{REFERENCES}

AFONSO, S. R.; ANGELO, H.; ALMEIDA, N. A. Caracterização da produção de pequi em Japonvar, MG. Revista Floresta, Curitiba, v. 45, n. 1, p. 49-56, 2015. DOI: http://dx.doi.org/10.5380/rf.v45i1.33987

ALVES, A. M.; FERNANDES, D. C.; SOUSA, A. G. O.; NAVES, R. V.; NAVES, M. M. V.; Características físicas e nutricionais de pequis oriundos dos estados de Tocantins, Goiás e Minas Gerais. Brazilian Journal of
Food Technology, Campinas, v. 17, n. 3, p. 198-203, 2014. DOI: http://dx.doi.org/10.1590/1981-6723.6013

ENCINA, C. C. C.; MARUQES, M. R.; DIODATO, M. A.; MOT'TA, J. S.; GODOI, R. F.; OLIVEIRA, J. R. S.; GAMARRA, R. M.; DALMAS, F. B.; FILHO, A. C. P. Análise da estrutura vegetal de fragmentos do bioma Cerrado através de sensoriamento remoto. Anuário do Instituto de Geociências, Rio de Janeiro, v. 41, n. 2, p. 585-597, 2018.2 DOI: http://dx.doi.org/10.11137/2018_2_585_597

FAGUNDES, M.; ARAÚJO, S. L.; NUNES, Y. R. F. Efeitos do estágio sucessional do habitat na fenologia do pequizeiro (Caryocar brasiliense: Caryocaraceae). Revista Brasileira de Biociências, Porto Alegre, v. 5, n. 1, p. 144-146, jul. 2007.

FARIA, R. A. P. G.; COELHO, M. F. B.; FIGUEIREDO E ALBUQUERQUE, M. C.; AZEVEDO, R. A. B. Fenologia de Brosimum gaudichaudii Trécul. (Moraceae) no Cerrado de Mato Grosso. Ciência Florestal, Santa Maria, v. 25, n. 1, p. 67-75, 2015. DOI: https://doi.org/10.1590/1980-509820152505067

FREITAS, J. L.; SANTOS, A. C., JUNIOR, F. O. C.; SARDINHA, M. A. Caracterização fenológica de três espécies florestais em ecossistema de terra firme, Amapá, Brasil. Enciclopédia Biosfera, Goiânia, v. 13, n. 24, p. 227-239, $2016 . \quad$ DOI: https://doi.org/10.18677/EnciBio_2016B_020

GARRATT, M. P. D.; BREEZE, T. D.; JENNER, N.; POLCE, C.; BIESMEIJER, J. C.; POTTS, S. G. Avoiding a bad apple: Insect pollination enhances fruit quality and economic value. Agriculture, Ecosystems and Environment, v. 184, n. 100, p. 34-40, 2014. DOI: https://doi.org/10.1016/j.agee.2013.10.032

GRIBEL, R. Ecologia da polinização e da dispersão de Caryocar brasiliense Camb. (Caryocaraceae) na região do Distrito Federal. 1986. 110f. Dissertação (Mestrado em Ecologia) - Universidade de Brasília, Brasília, 1986.

HOLZSCHUH, A.; DUDENHÖFFER, J.H.; TSCHARNTKE, T. Landscapes with wild bee habitats enhance pollination, fruit set and yield of sweet cherry. Biological Conservation, v. 153, p. 101-107, 2012. DOI: https://doi.org/10.1016/j.biocon.2012.04.032

Instituto Nacional de Meteorologia (INMET). Banco de Dados Meteorológicos para Ensino e Pesquisa. Disponível <http://www.inmet.gov.br/portal/index.php?r=bdmep /bdmep>. Acesso em: 20 fev 2019.

KINUPP, V. F.; LORENZI, H. Plantas Alimentícias Não Convencionais (PANC) no Brasil. v.2. São Paulo: Instituto Plantarum de Estudos da Flora, 2014. 768 p.

KRAUSE, W.; NEVES, L. G.; VIANA, A. P.; ARAÚJO, C. A. T.; FALEIRO, F. G. Produtividade e qualidade de frutos de cultivares de maracujazeiro-amarelo com ou sem polinização artificial. Pesquisa Agropecuária Brasileira, Brasília, v. 47, n. 12, p. 1.737-1742, 2012.

MARTINS, R. L.; GRIBEL, R. Polinização de Caryocar villosum (Aubl.) Pers. (Caryocaraceae) uma árvore emergente da Amazônia central. Revista Brasileira de Botânica, São Paulo, v. 30, n. 1, p. 35-43, 2007. DOI: https://doi.org/10.1590/S0100-84042007000100005

MEDEIROS, H.; AMORIM, A. M. A. Caryocaraceae in Flora do Brasil 2020 em construção. Jardim Botânico do Rio de Janeiro. Disponível em: 
$<$ http://floradobrasil.jbrj.gov.br/reflora/floradobrasil/ FB80>. Acesso em: 30 mar 2020.

MOURA, N. F.; CHAVES L. J.; NAVES, R. V.; Caracterização física de frutos de pequizeiro (Caryocar brasiliense Camb.) do Cerrado. Revista Árvore, Viçosa, v. 37, n. 5 p. 905-912, 2013. DOI: https://doi.org/10.1590/S0100-67622013000500013

NASCIMENTO, R. S. M.; COCOZZA, F. D. M. Physicochemical characterization and biometry of fruits of 'pequi' in Western Bahia. Revista Brasileira de Engenharia Agrícola e Ambiental, Campina Grande, v. 19 , n. 8 , p. 791-796, 2015. DOI: http://dx.doi.org/10.1590/18071929/agriambi.v19n8p791-796

NASCIMENTO-SILVA, N. R. R.; NAVES, M. M. V. Potential of Whole Pequi (Caryocar spp.) Fruit-Pulp, Almond, Oil, and Shell-as a Medicinal Food. Journal Of Medicinal Food, Larchmont, v. 22, n. 9, p. 952-962, 2019. DOI: http://dx.doi.org/10.1089/jmf.2018.0149

NUNES, E. de S.; SOUSA, E. P.; DAMASCENO, N. P. Competitividade da extração e comercialização do pequi no Ceará. Custos e Agronegócio, Recife, v. 12, n. 1, p. 245-264, 2016.

OLIVEIRA, P. E. Fenologia e biologia reprodutiva das espécies de Cerrado. In: SANO, S. M.; ALMEIDA, S. P.; RIBEIRO, J. F. (Eds.). Cerrado: ecologia e flora. Brasília: Embrapa Informação Tecnológica, 2008. p. 273 290

PANASOLO, A.; GALVÃO, F.; HIGACHI, H. Y.; OLIVEIRA, E. D.; CAMPOS, F.; WROBLEWSKI, C. A. Percepção dos serviços ecossistêmicos de áreas verdes urbanas de Curitiba/PR. BIOFIX, Curitiba, v. 4, n. 1, p. 70-80, 2019. DOI: dx.doi.org/10.5380/biofix.v4i1.64451

PERUCH, L. A. M.; COLARICCIO, A.; BATISTA, D. C. Controle de doenças do maracujazeiro: situação atual e perspectivas. Agropecuária Catarinense, Florianópolis, v. 21, n. 1, p. 37-40, 2018.

PIMENTEL-GOMES, F.; GARCIA，C. H. Estatística aplicada a experimentos agronômicos e florestais: exposição com exemplos e orientações para uso de aplicativos. 1.ed. Piracicaba: Fealq, 2002, 309 p.

PLATAFORMA BRASILEIRA DE BIODIVERSIDADE E SERVIÇOS ECOSSISTÊMICOS (BPBES). Relatório Temático sobre Polinização, Polinizadores e
Produção de Alimentos no Brasil. Disponível em: <https://www.bpbes.net.br/wpcontent/uploads/2019/ 02/BPBES_Completov5.pdf>. Acesso em: 13 mai 2019.

PROENÇA, I. C. L.; MASSAROTO, J. Á.; THEODORO, V. C. A. Agricultura orgânica no município de Alta Floresta-MT: estudo de caso em propriedades de base familiar. Revista de Ciências Agroambientais, Alta Floresta, v. 14, n. 1, p. 119-130, 2016.

REIS, S. M.; MARIMON-JÚNIOR, B. H.; MORANDI, O. S. OLIVEIRA-SANTOS, C.; OLIVEIRA, B.; MARIMON, B. S. Desenvolvimento inicial e qualidade de mudas de Copaifera langsdorffii Desf. sob diferentes níveis de sombreamento. Ciência Florestal, Santa Maria, v. 26 , n. 1 , p. 11-20, 2016. DOI: https://doi.org/10.5902/1980509821061

SILVÉRIO, D. V.; LENZA, E. Fenologia de espécies lenhosas em um cerrado típico no Parque Municipal do Bacaba, Nova Xavantina, Mato Grosso, Brasil. Biota Neotropica, Campinas, v. 10, n. 3, p. 205-216, 2010. DOI: $\quad$ https://doi.org/10.1590/S167606032010000300024 .

UIEDA, W.; BRED, A. Morcegos: agentes negligenciados da sustentabilidade. Sustentabilidade em Debate, Brasília, v. 7 , n. 1, p. 186-209, 2016. DOI: https://doi.org/10.18472/SustDeb.v7n1.2016.18617

YAMAMOTO, M.; OLIVEIRA, P. E.; GAGLIANONE, M. C. Uso sustentável e restauração da diversidade dos polinizadores autóctones na agricultura e nos ecossistemas relacionados: Planos de Manejo. 1.ed. Rio de Janeiro: Funbio, 2014. 404 p.

ZUFFO, A. M.; ANDRADE, F. R. E.; ZUFFO-JÚNIOR, J. M. Caracterização biométrica de frutos e sementes de baru (Dipteryx alata Vog.) na região leste de Mato Grosso, Brasil. Revista de Ciências Agrárias, Lisboa, v. 37, n. 4, p. 463-471, 2014.

ZUFFO, A. M.; GESTEIRA, G. S.; ZUFFO-JÚNIOR, J. M.; ANDRADE, F. R.; SOARES, I. O.; ZAMBIAZZI, E. V.; GULHERME, S. R.; SANTOS, A. S. Caracterização biométrica de frutos e sementes de mirindiba (Buchenavia tomentosa Eichler) e de inajá (Attalea maripa [Aubl.] Mart.) na região sul do Piauí, Brasil. Revista de Ciências Agrárias, Lisboa, v. 39, n. 3, p. 331340, 2016.

DOI: http:/ /dx.doi.org/10.19084/RCA15152 